\title{
Original cast list
}

The first full performance of Sir David Lindsay's play was given on Castlehill in Cupar on 7 th June 1552. This adaptation was commissioned by $2000 \& 3$ ESTAITES with the support of the Millennium Festival Fund. As part of the company's Millennium project, performances of parts of an earlier draft of this adaptation were given by The Dunlop Players, Borders Youth Theatre, Dunfermline Children's Heritage Theatre and Rothes Halls Youth Theatre during March to May 2000. 2000 \& 3 ESTAITES first performed The Proclamation at the Mercat Cross in the High Street in Edinburgh and Ferguson Square in Cupar on 28th April 2000. The first full performance of this adaptation was given by $2000 \& 3$ ESTAITES on Castlehill in Cupar on 2nd July 2000 in the version printed here. In that performance, the cast (in order of speaking) were:

\section{The Proclamation}

DILIGENCE, a herald

COTTAR

MRS COTTAR

FINLAY THE FITBA FAN

THE FOOL
John A. Sampson

Alan Redpath

Fiona A. Hunter

John K. Marshall

David Hunter

\section{The Play}

DILIGENCE, a herald

KING HUMANITY

WANTONNESS, courtier to the King

CHILL-OOT, courtier to the King

SANDY SOLACE, courtier to the King
John A. Sampson

David Hunter

Alastair Sim

Andrew Laughton

Martin Butler 
DAME SENSUALITY

HAMELINESS, handmaiden to Sensuality

DANGER, handmaiden to Sensuality

JANET, handmaiden to Sensuality

GUID COUNSEL, a Virtue

FLATTERY, a Vice who masquerades as 'Devotion'

FALSEHOOD, a Vice who masquerades as 'Sanity'

Matthew Burgess

DECEIT, a Vice who masquerades as 'Discretion' Robert Pattison VERITY, a Virtue

Kate Potter THE BISHOP, head of the Spiritual Estaite Charles K. Gallacher THE PRIORESS, member of the Spiritual Estaite THE PARSON, member of the Spiritual Estaite CHASTITY, a Virtue Catherine Beckley TEMPORALITY, head of the Estaite of Craftsmen MERCHANT, head of the Estaite of Merchants SOUTAR, a craftsman TAYLOR, a craftsman JENNY TAYLOR MRS TAYLOR MRS SOUTAR DIVINE CORRECTION'S VARLET

Danielle Corr/Donna Sutherland/Jennifer Boulton DIVINE CORRECTION THE POOR MAN JANE THE COMMON-WEIL FIRST SERGEANT SECOND SERGEANT FOLLY
Michael Mackenzie Alastair Ferguson-Smith Gerda Stevenson Fiona Dingwall Fiona A. Hunter Michael Mackenzie

Directed by John Carnegie

Designed by Elaine Robertson

Music by Gordon Dougall 

David Lindsay's

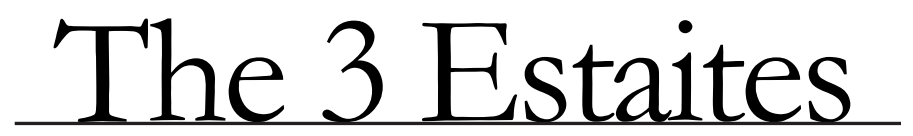

The Millennium version by Alan Spence 


$$
\begin{gathered}
\text { To } \\
\text { John Carnegie }
\end{gathered}
$$




\section{Caution}

Amateur performances by schools and colleges in Scotland for assessment and educational purposes are authorised. Applications for public performance by amateurs or professionals must be addressed to Curtis Brown Ltd, 37 Queensferry Street, Edinburgh EH2 4QS (telephone 0131225 1286).

No public performances may be given unless a licence has been obtained. Applications should be made in writing before rehearsals begin.

(C) Alan Spence, 2002

Edinburgh University Press Ltd

22 George Square, Edinburgh

First published by Learning and Teaching Scotland in 2002

Printed and bound in Great Britain by

The Cromwell Press Litd, Trowbridge, Wilts

A CIP Record for this book is available from the British Library

ISBN 0748617469 (paperback)

The right of Alan Spence to be identified as author of this work has been asserted in accordance with the Copyright, Designs and Patents Act 1988.

The publishers acknowledge financial assistance in the publication of this volume from 2000 \& 3 ESTAITES with funds originally derived from the Millennium Festival Fund. 